Jurnal Mandala Pharmacon Indonesia, Vol 6.No.1 Juni 2020

Avaiable online at www.jurnal-pharmaconmw.com/jmpi

p-ISSN : 2442-6032

$e$-ISSN : 2598-9979

\title{
Efek Antidiabetes Kombinasi Ekstrak Etanol Daun Pandan Wangi (Pandanus amaryllifolius Roxb.) Dan Daun Salam (Syzygium polyanthum Wight.) Pada Tikus Putih Dengan Metode Induksi Aloksan
}

\author{
Nikeherpianti Lolok, Wa Ode Yuliastri, Fiqri Algafiq Abdillah \\ Program Studi Farmasi, STIKES Mandala Waluya, Kendari \\ Corresponding author email : nikeherpianti.apt@gmail.com
}

\begin{abstract}
ABSTRAK
Diabetes melitus (DM) ditandai dengan terjadinya hiperglikemi. Indonesia menempati urutan ke 7 dengan penderita DM sejumlah 8,5 juta. Penggunan obat bahan alam sudah banyak digunakan secara empiris oleh masyarakat, diantaranya Ekstrak Daun Pandan Wangi dan Daun Salam masing-masing telah dilaporkan memilikiefek hipoglikemik dan berpotensi sebagai antioksidan yang dapat memperbaiki sel-sel tubuh yang rusak, termasuk pankreas. Tujuan penelitian ini adalah untuk mengetahui kombinasi Ekstrak Daun Pandan Wangi (Pandanus amaryllifolius Roxb.) dan Daun

menjadi 3 kelompok yaitu kelompok kontrol positif, kombinasi ekstrak dan kelompok kontrol negatif. Analisis data dilakukan dengan menggunakan uji Kruskal- Wallis dan dilanjutkan dengan uji MannWhitney. Hasil uji terhadap tikus yang diinduksi diabetes menunjukkan bahwa kombinasi ekstrak etanol daun pandan wangi dan daun salam secara signifikan mampu menurunkan kadar gula darah pada tikus yang diinduksi diabetes dibandingkan kontrol negatif $(\mathrm{p}<0,05)$, dan hasilnya tidak berbeda nyata dengan kelompok kontrol positif ( $>>0,05)$.
\end{abstract} Salam (Syzygium polyanthum Wight.) memberikan efek dalam penurunan kadar gula darah pada tikus (Rattus norvegicus) putih galur wistar yang diinduksi diabetes dibandingkan dengan kelompok negatif dan kelompok positif. Penelitian ini merupakan penelitian eksperimental laboratorium. Sampel diekstraksi dengan metode maserasi menggunakan pelarut etanol 96\%. Pengujian efek antidiabetes hewan uji dibagi
Kata Kunci: Daun Pandan Wangi, Daun Salam, Diabetes Mellitus, Aloksan

\section{Penulis Korespondensi :}

Nikeherpianti Lolok

Program Studi Farmasi, STIKES Mandala Waluya, Kendari

E-mail : nikeherpianti.apt@gmail.com 


\section{PENDAHULUAN}

Diabetes melitus (DM) ditandai dengan terjadinya hiperglikemik. Pada DM terjadi penumpukan gula dalam darah sehingga insulin gagal masuk ke dalam sel. Peningkatan kadar gula darah dalam darah atau hiperglikemia adalah kondisi terjadinnya abnormalitas metabolisme karbohidrat, lemak, dan protein yang disebabkan oleh penurunan sekresi insulin atau penurunan sensitivitas insulin atau keduanya dan menyebabkan komplikasi kronis mikrovaskular, makrovaskular, dan neuropati (Nurarif dan Kusuma, 2015). Kegagalan tersebut terjadi akibat kurangnya hormon insulin atau cacat fungsi. Hormon insulin merupakan hormon yang membantu masuknya gula darah (WHO, 2016).Dalam metabolisme tubuh hormon insulin bertanggung jawab dalam mengatur kadar glukosa darah. Hormon ini diproduksi dalam pankreas kemudian dikeluarkan untuk digunakan sebagai sumber energi. Apabila di dalam tubuh kekurangan hormon insulin maka dapat menyebabkanhiperglikemi (IDF, 2015).

Diabetes melitus merupakan salah satu penyakit yang menjadi masalah kesehatan yang paling serius yang dihadapi masyarakat di dunia seabad terakhir ini. Diabetes melitus (DM) telah membunuh 38 juta orang setiap tahunnya. Indonesia merupakan negara menempati urutan ke 7 dengan penderita DM sejumlah 8,5 juta penderita setelah Cina,
India dan Amerika Serikat, Brazil, Rusia, Mexico (IDF, 2015). Salah satu tujuan terapi bagi penderita Diabetes melitus yaitu pengontrolan kadar gula darah dengan pemberian obat hipoglikemik oral maupun insulin. Namun, sering kali terdapat efek samping yang tidak diinginkan. Oleh karena itu, peneliti tertarik untuk melakukan penelitian yang menggunakan sumber bahan alam sebagai salah satu alternatif dalam menangani penyakit diabetes melitus (Lolok et al, 2019).

Telah banyak masyarakat yang menggunakan obat tradisional dari bahan alam sebagai penyembuhan berbagai macam penyakit, sehingga dengan memanfaatkan sumberdaya alam di Indonesia dilakukan eksplorasi bahan alam yang akan menjadi sumber dalam pencarian obat baru. Beberapa tumbuhan yang sering dimanfaatkan oleh masyarakat secara empiris sebagai obat diabetes melitus yaitu daun pandan wangi dan daun salam sebagai penurunan kadar gula darah. Penggunaan bersama pada daun pandan wangi (Pandanus amaryllifolius Roxb.) dan daun salam (Syzygium polyanthum Wight.) memberikan efek yang sinergis yaitu pada penelitian yang dilakukan oleh Prasmeswari dan Widjanarko (2014), menunjukkan ekstrak air daun pandan wangi (Pandanus amaryllifolius Roxb.) dapat menurunkan kadar glukosa darah dan memperbaiki kerusakan jaringan 
pankreas, sedangkan kandungan senyawa yang terdapat pada daun salam diantaranya yaitu alkaloid dan saponin dapat menstimulasi sekresi insulin dari sel beta pankreas (Patel. et al, 2012; Murray. et al, 2003), serta terpenoid seperti triterpenoid dapat dapat meningkatkan penyerapan glukosa dengan bertindak meniru kerja insulin dan sebagai insulin sensitizer (Lee dan Thuong, 2010).

Pada peneliti sebelumnya menyatakan bahwa ekstrak daun pandan wangi mengandung senyawa kimia flavonoid yang juga mampu menurunkan kadar glukosa darah pada tikus diabetik dengan cara menghambat kerja dari GLUT2 (Glucose Transporter Isoform 2), suatu protein transporter glukosa yangterdapat pada membran usus yang menyebabkan kadar glukosa darah akan turun (Song J, et al, 2002), flavanoid juga dapat berfungsi sebagai antioksidan alami, sehingga dapat memperbaiki kerusakan jaringan pankreas yang diakibatkan alkilasi DNA akibat induksi aloksan akibatnya dapat memperbaiki morfologi pankreas tikus (Prasmeswari dan Widjanarko, 2014). Penelitian lainnya yang dilakukan oleh Widyawati et al., (2014) menyimpulkan bahwa kandungan flavonoid yang terkandung di dalam daun salam merupakan salah satu golongan senyawa yang dapat menurunkan kadar glukosa darah.

Penggunaan bersama pada daun pandan wangi

(Pandanus
amaryllifoliusRoxb.) dan daun salam (Syzygium polyanthum Wight.) memberikan efek yang sinergis yaitu pada penelitian yang dilakukan oleh Prasmeswari dan Widjanarko (2014), menunjukkan ekstrak air daun pandan wangi (Pandanus amaryllifolius Roxb.) dapat menurunkan kadar glukosa darah dan memperbaiki kerusakan jaringan pankreas, sedangkan kandungan senyawa yang terdapat pada daun salam diantaranya yaitu alkaloid dan saponin dapat menstimulasi sekresi insulin dari sel beta pankreas (Patel. et al., 2012; Murray. et al., 2003), serta terpenoid seperti triterpenoid dapat dapat meningkatkan penyerapan glukosa dengan bertindak meniru kerja insulin dan sebagai insulin sensitizer (Lee dan Thuong, 2010).

Berdasarkan hal tersebut, peneliti ingin mengetahui efek dari kombinasi ekstrak etanol daun pandan wangi(Pandanus amaryllifolius Roxb.) dan daun salam(Syzygium polyanthum Wight.) jika dibandingkan dengan potensi hipoglikemik dari insulin pada tikus (Rattus norvegicus) putih galur wistar dengan metode induksi Aloksan. Sehingga hasil penelitian ini dapat menjadi referensi dalam penemuan senyawa obat baru untuk mengatasi penyakit diabetes melitus.

\section{METODE PENELITIAN}

Penelitian ini dilaksanakan pada Bulan April hingga Mei 2019. Penelitian 
ini merupakan penelitian eksperimental laboratorium yang bertujuan untuk mengetahui efek antidiabetes kombinasi ekstrak etanol daun pandan wangi (Pandanus amaryllifolius Roxb.)dan daun salam (Syzygium polyanthum Wight.) pada tikus(Rattus norvegicus) putih galur wistar dengan metode induksi aloksan..

\section{A. Alat Penelitian}

Alat-alat yang digunakan adalah seperangkat alat ekstraksi, rotary evaporator (Buchi), corong (Herma), timbangan analitik (Ohouse USA), penangas air (Intralab Instrument), kertas saring(Hario V6o), spoit injeksi (Onemed), jarum oral tikus (Onemed), mortir dan stamper (Powerbond), gunting (Stainless), dan seperangkat alat untuk uji kadar gula darah : glukometer (Nesco), strip glukometer (Nesco).

\section{B. Bahan Penelitian}

Bahan-bahan yang digunakan adalah akuades, etanol 96\%, aloksan monohidrat, hewan coba, pakan hewan coba, Daun Pandan Wangi (Pandanus amaryllifolius Roxb.), Daun Salam (Syzygium polyanthum Wight.) Natrium Karboksi Metil Selulosa (Na-CMC), dan insulin eksogen (Novomix).

\section{Prosedur Kerja}

1.Pengambilan Sampel

Sampel Daun Pandan Wangi (Pandanus amaryllifolius Roxb.) yang digunakan dalam penelitian ini diambil dari, Kecamatan Anggotoa, Kabupaten
Konawe, Provinsi Sulawesi Tenggara, sedangkan daun salam (Syzygium polyanthum Wight.) diambil dari Kelurahan Tobuha, Kecamatan Puuwatu, Kota Kendari, Provinsi Sulawesi Tenggara. 2. Determinasi Sampel

Tanaman yang diperoleh dilakukan determinasi di Laboratorium Biologi Fakultas Keguruan dan Ilmu Pendidikan Universitas Halu Oleo.

3. Pengolahan Sampel

Sampel daun Pandan Wangi (Pandanus amaryllifolius Roxb.), dan daun Salam (Syzygium polyanthum Wight.) dicuci bersih dengan air mengalir, kemudian dikeringkan dengan cara diangin - anginkan tanpa sinar matahari langsung, lalu dirajang.

4. Ekstraksi Sampel

Sampel daun Pandan Wangi (Pandanus amaryllifolius Roxb.), dan daun Salam (Syzygium polyanthum Wight.)yang telah dirajang masingmasing diekstraksi dengan metode maserasi menggunakan cairan penyari etanol 96\% dengan perbandingan sampel dan cairan penyari $1: 3$. Proses maserasi ini dilakukan selama 3 x 24 jam dengan sesekali pengadukan, kemudian diambil filtratnya dan ampasnya diremaserasi kembali dengan cairan penyari yang baru sampai pelarutnya menjadi bening dan disatukan, ekstrak lalu diuapkan dengan rotary evaporator.

5. Penentuan Parameter Standarisasi

1. Parameter Spesifik 
a. Penentuan Kadar Senyawa yang Larut Dalam Air

Sejumlah 1,0 g ekstrak dimasukkan ke dalam labu bersumbat dan ditambahkan 25,0 $\mathrm{mL}$ air-kloroform LP $(2,5 \mathrm{~mL}$ kloroform dimasukkan dalam labu ukur $1000 \mathrm{~mL}$ dan ditambahkan air hingga tanda batas). Kemudian didiamkan selama 24 jam sambil dikocok berkali-kali selama 6 jam pertama dan dibiarkan selama 18 jam lalu disaring. Sebanyak 5,o mL filtrat diuapkan hingga kering dalam cawan dangkal berdasar rata yang telah ditara. Lalu residu dipanaskan pada suhu $105^{\circ} \mathrm{C}$ hingga bobot tetap. Kadar dalam persen senyawa yang larut air dihitung terhadap ekstrak awal (Saifudin, Rahayu, \& Teruna,2011).

b. Penentuan Kadar Senyawa Larut Dalam Etanol

Sejumlah 1,0 g ekstrak dimasukkan ke dalam labu bersumbat dan ditambahkan 25,0 $\mathrm{mL}$ etanol (96\%). Kemudian didiamkan selama 24 jam sambil dikocok berkali-kali selama 6 jam pertama dan dibiarkan selama 18 jam. Lalu disaring dengan cepat untuk menghindarkan penguapan etanol. Sebanyak 5,0 mL filtrat diuapkan hingga kering dalam cawan dangkal berdasar rata yang telah ditara. Residu dipanaskan pada suhu $105^{\circ} \mathrm{C}$ hingga bobot tetap. Kadar dalam persen senyawa yang larut etanol (95\%) dihitung terhadap ekstrak awal

6. Penyiapan Sampel Bahan Penelitian

a. Pembuatan larutan koloidal Na CMC $0,5 \% \mathrm{~b} / \mathrm{v}$

Aquadest sebanyak $100 \mathrm{ml}$ dipanaskan hingga suhu $70^{\circ} \mathrm{C}$ lalu dimasukkan kedalam lumpang. Natrium CMC sebanyak $0,5 \quad \mathrm{~g}$ dimasukkan sedikit demi sedikit dan diaduk hingga terbentuk suspensi yang homogen, kemudian volumenya dicukupkan dengan air panas hingga volume $100 \mathrm{ml}$.

b. Pembuatan Suspensi Ekstrak Etanol Daun Pandan Wangi (EEDPW) dan Ekstrak Etanol Daun Salam (EEDS)

Pembuatan suspensi EEDPW dan EEDS dilakukan dengan cara sebagai berikut: sebanyak $12 \mathrm{mg} / \mathrm{ml}$ EEDPW dan $12,5 \mathrm{mg} / \mathrm{ml}$ EEDS dimasukkan kedalam vial yang berbeda, kemudian diukur suspensi Na CMC 0,5\% dalam gelas ukur $10 \mathrm{ml}$, setelah itu dimasukkan kedalam masing-masing vial yang berisi EEDPW dan EEDS. dikocok hingga homogen.

\section{Pengujian}

a. Pengkondisian Hewan Coba 
Hewan coba yang digunakan pada penelitian ini adalah tikus jantan galur Wistar yang berusia 8 minggu dengan berat badan antara 150-200 g. Hewan coba diadaptasikan dalam kandang percobaan satu minggu sebelum diberi perlakuan. Hewan coba diberi pakan pelet diet standar dan air minum ad libitum (Sornalakshmi dkk., 2016; Suresha dkk., 2012).

b. Induksi Diabetes Pada Hewan Coba

Pada hari pertama sebelum perlakuan, semua tikus dipuasakan, kemudian diperiksa kadar gula darah puasanya. Induksi diabetes pada hewan coba dilakukan dengan pemberian aloksan monohidrat $(150 \mathrm{mg} / \mathrm{kg}$ BB) secara intraperitoneal. Kadar gula darah tikus diperiksa kembali pada hari kedua, 24 jam setelah penyuntikan aloksan. Parameter keberhasilan penginduksian yaitu naiknya kadar glukosa darah puasa yang melebihi $125 \mathrm{mg} / \mathrm{dL}$ (Anitha dkk., 2012; Sornalakshmi dkk., 2016, Etuk., 2010; Swastini, 2018; ADA, 2014).

c. Pengujian Efek Antidiabetes

Pada pengujian ini hewan uji dibagi menjadi 3 kelompok pada uji toleransi glukosa oral pada tikus yang diinduksi diabetes. Tiap kelompok terdiri dari 3 tikus. Uji Toleransi Glukosa pada Tikus yang Diinduksi Diabetes

Kelompok I : Kontrol Negatif (Na CMC)

$\begin{array}{cc}\text { Kelompok II } \quad: & \text { Kontrol } \\ \text { Positif } & \text { (Insulin } \\ \text { eksogen) } & \end{array}$

Kelompok III : Kombinasi ekstrak ekstrak etanol daun pandan wangi (6oo $\mathrm{mg} / \mathrm{kg} \mathrm{BB}$ ) dan daun salam (625 mg/kg BB) per oral.

Setelah 3 hari pelakuan, masing-masing kelompok tikus dilakukan pemeriksaan kadar gula darah, kemudian dilanjutkan perlakuan hingga hari ke-15 dan dilakukan pemeriksaan kadar gula darah untuk semua kelompok tikuss pada jam ke-o, 6, 12, 18, dan 24. Semua sampel darah diambil melalui pemotongan ujung ekor tikus dan kadar gula darah diukur dengan glukometer. Masing masing pengambilan sampel darah dilakukan dengan replikasi tiga kali.

\section{Pengumpulan dan Pengelolaan}

\section{Data}

Hasil penelitian dinyatakan dalam rata-rata \pm SEM. Signifikansi data dianalisis dengan One-way Analysis of Variance (ANOVA) (program SPSS 16.0). 
Data dianggap signifikan jika nilai $\mathrm{p}$

kurang dari 0,05 .

\section{HASIL DAN PEMBAHASAN}

\section{Hasil Karakterisasi Simplisia}

\section{Tabel 3. Hasil Karakterisasi Simplisia}

1. Daun Pandan Wangi

\begin{tabular}{lll}
\hline No & Karakterisasi & Hasil \\
\hline 1. & Penetapan kadar senyawa larut air & $\mathbf{1 1 \%}$ \\
\hline 2. & Penetapan kadar senyawa larut etanol & $9 \%$ \\
\hline
\end{tabular}

1. Daun Salam

\begin{tabular}{lll}
\hline No & Karakterisasi & Hasil \\
\hline 1. & Penetapan kadar senyawa larut air & $\mathbf{1 1 \%}$ \\
\hline 2. & Penetapan kadar senyawa larut etanol & $\mathbf{1 1 \%}$ \\
\hline
\end{tabular}

\section{Hasil Pengukuran Kadar Gula Darah Tikus Putih}

Tabel 4. Hasil Rata-rata Pengukuran Kadar Gula Darah Sebelum dan SesudahInduksiDiabetes:

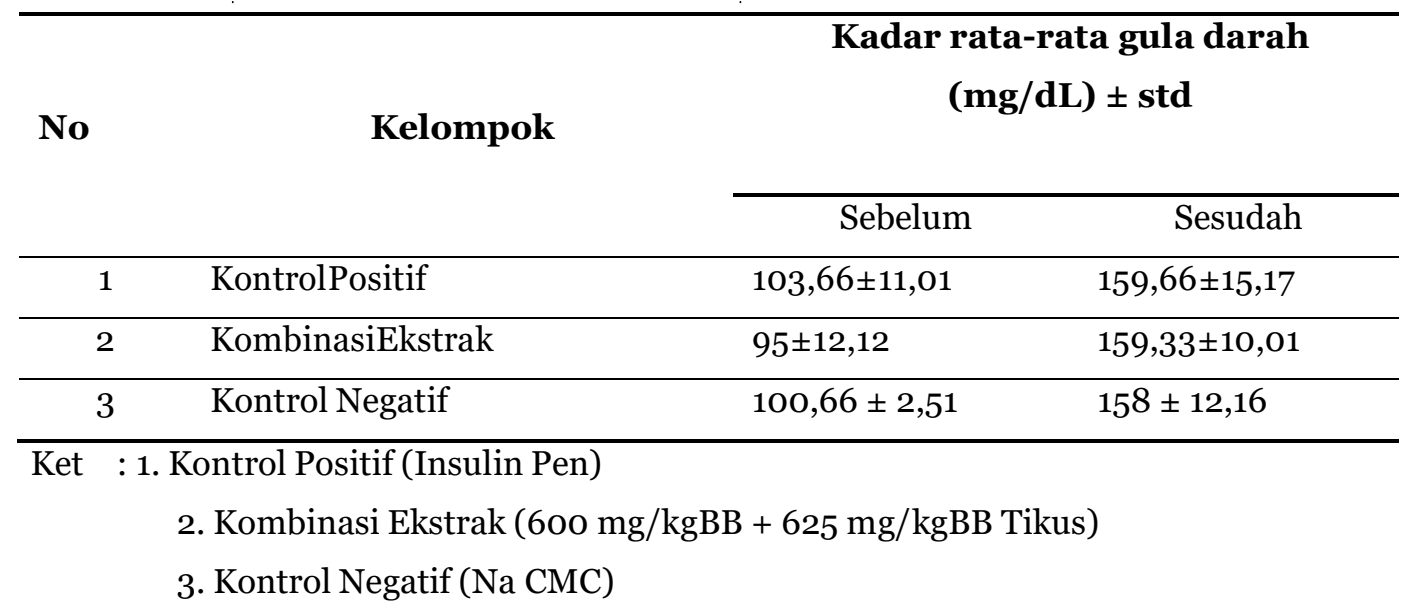

Hasil pengukuran rata-rata kadar gula darah Tikus (Rattus norvegicus) $\mathrm{H}+3$ dan $\mathrm{H}+15$ dapat dilihat pada tabel berikut:

Tabel5.HasilPengukuranRata-rataKadarGulaDarahpadaH+3:

\begin{tabular}{llccccc}
\hline \multirow{2}{*}{ No } & \multirow{2}{*}{ Kelompok } & \multicolumn{5}{c}{ Kadarr rata-rata gula darah tikus (mg/dL) \pm std } \\
\cline { 3 - 7 } & & 0 & 6 & 12 & 18 & 24 \\
\hline 1 & KontrolPositif & $99,3 \pm 21,3$ & $91,3 \pm 21,3$ & $88,3 \pm 25,1$ & $87 \pm 15,71$ & $94,3 \pm 24,6$ \\
\hline 2 & Kombinasi & $110,3 \pm 8,3$ & $100,6 \pm 2,8$ & $92,3 \pm 10,9$ & $82 \pm 9,8$ & $88,3 \pm 14,1$ \\
& Ekstrak & & & & & \\
\hline 3 & Kontrol Negatif & $177,3 \pm 6,6$ & $172,6 \pm 19,6$ & $162,6 \pm 4,6$ & $176,3 \pm 8,5$ & $178,3 \pm 9,0$ \\
\hline
\end{tabular}


Tabel6.HasilPengukuranRata-rataKadarGulaDarahpadaH+15:

\begin{tabular}{llccccc}
\hline \multirow{2}{*}{ No } & \multirow{2}{*}{ Kelompok } & \multicolumn{5}{c}{ Kadarr rata-rata gula darah tikus (mg/dL) \pm std } \\
\cline { 3 - 6 } & & 0 & 6 & 12 & 18 & 24 \\
\hline 1 & $\begin{array}{l}\text { Kontrol } \\
\text { Positif }\end{array}$ & $111 \pm 16,3$ & $129,3 \pm 16,2$ & $106,3 \pm 30,1$ & $110 \pm 32,5$ & $91,3 \pm 6,8$ \\
\hline 2 & $\begin{array}{l}\text { Kombinasi } \\
\text { Ekstrak }\end{array}$ & $128 \pm 4,3$ & $105,6 \pm 23,2$ & $105,3 \pm 15,0$ & $90 \pm 9$ & $81,6 \pm 7,0$ \\
\hline 3 & $\begin{array}{l}\text { Kontrol } \\
\text { Negatif }\end{array}$ & $185 \pm 4,5$ & $172 \pm 5,2$ & $176,3 \pm 5,8$ & $177,6 \pm 6,0$ & $180 \pm 1,7$ \\
\hline
\end{tabular}

Grafik hasil pengkuran kadar gula dalam darah tikus putih pada $\mathrm{H}+3$ dapat dilihat pada gambar berikut :

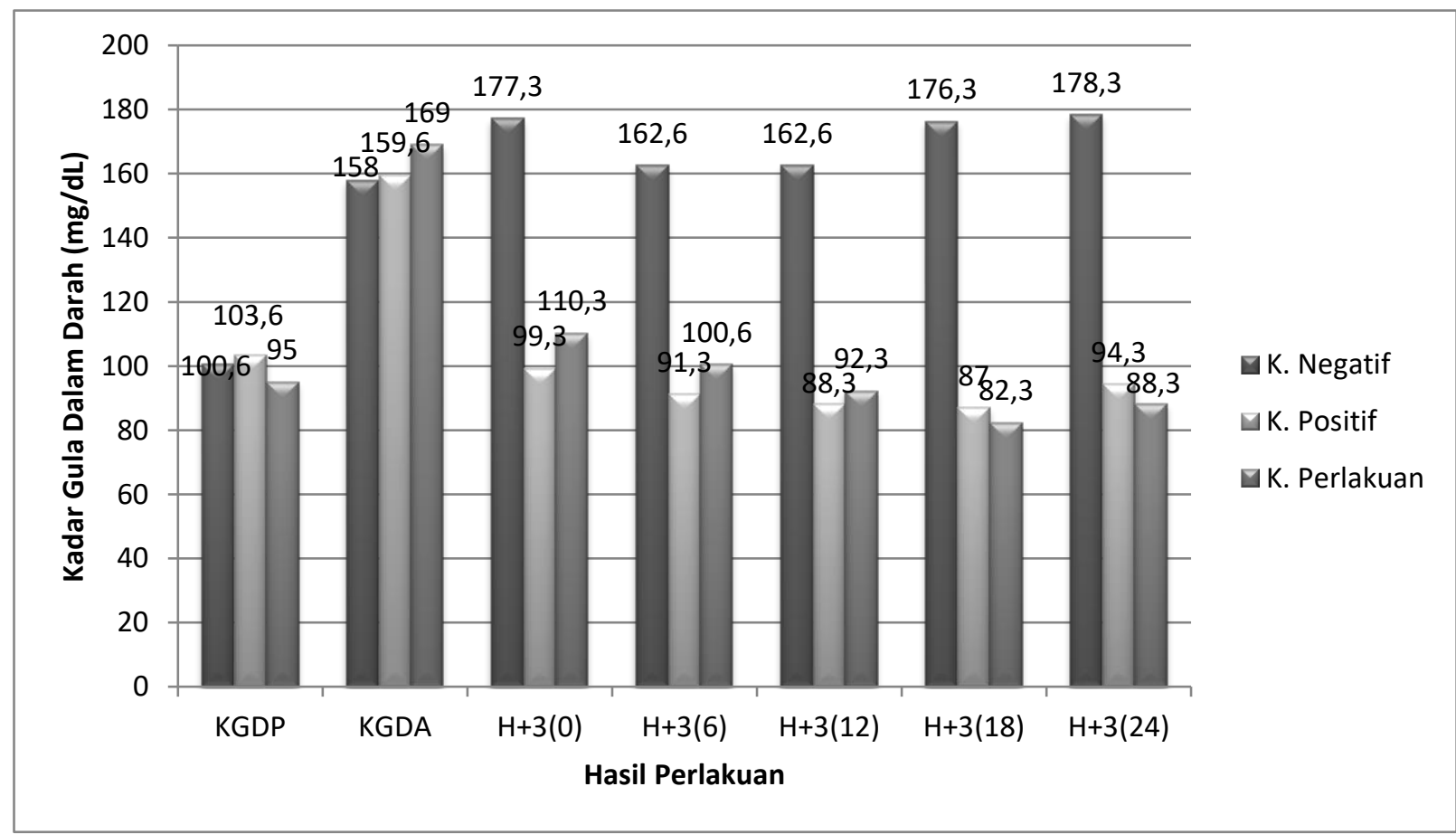

Gambar 1. Hasil Pengukuran Kadar Gula Darah Tikus Putih pada $\mathrm{H}+3$

Ket : KGDP : Kadar Gula Darah Puasa (mg/dL)

KGDA : Kadar Gula Darah 24 jam Setelah Induksi Aloksan (mg/dL)

$\mathrm{H}+3(\mathrm{o}) \quad$ : Kadar Gula Darah $\mathrm{H}+3$ Perlakuan jam ke- o (mg/dL)

$\mathrm{H}+3(6) \quad$ : Kadar Gula Darah $\mathrm{H}+3$ Perlakuan jam ke- 6 (mg/dL)

$\mathrm{H}+3(12) \quad$ : Kadar Gula Darah $\mathrm{H}+3$ Perlakuan jam ke- $12(\mathrm{mg} / \mathrm{dL})$

$\mathrm{H}+3(18) \quad$ : Kadar Gula Darah $\mathrm{H}+3$ Perlakuan jam ke- 18 (mg/dL)

$\mathrm{H}+3$ (24) : Kadar Gula Darah H+3 Perlakuan jam ke- $24(\mathrm{mg} / \mathrm{dL})$ 
Hasil pengkuran kadar gula dalam darah tikus putih pada $\mathrm{H}+15$ dapat dilihat pada gambar berikut :

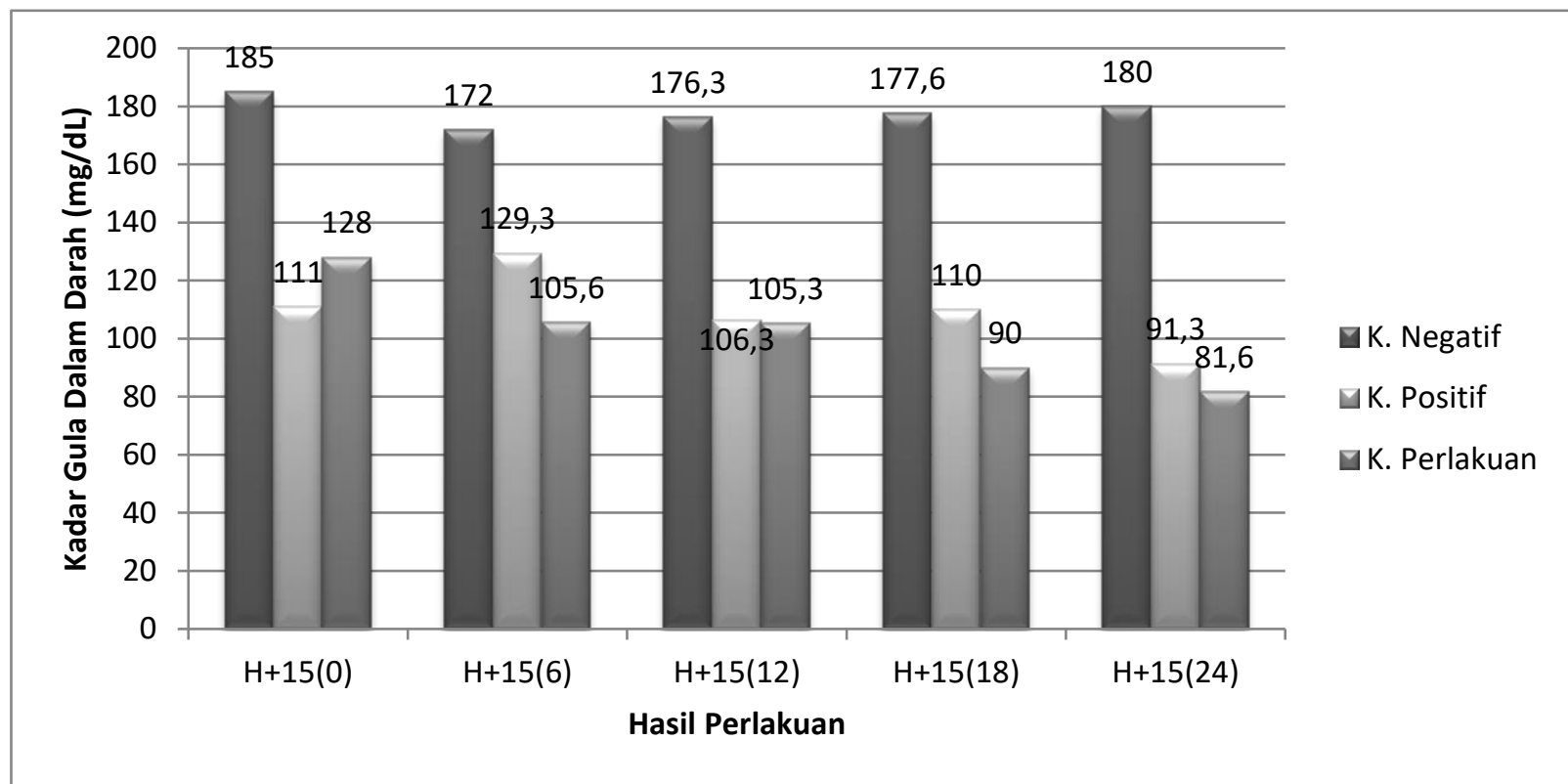

Gambar 2. Hasil Pengukuran Kadar Gula Darah Tikus Putih pada H+15

\begin{tabular}{|c|c|c|}
\hline Ket : & $\mathrm{H}+15(\mathrm{O})$ & : Kadar Gula Darah H+15 Perlakuan jam ke- o (mg/dL) \\
\hline & $\mathrm{H}+15(6)$ & : Kadar Gula Darah H+15 Perlakuan jam ke- 6 (mg/dL) \\
\hline & $\mathrm{H}+15(12)$ & : Kadar Gula Darah H+15 Perlakuan jam ke- 12 (mg/dL) \\
\hline & $\mathrm{H}+15(\underline{0,05} 18)$ & : Kadar Gula Darah H+15 Perlakuan jam ke- 18 (mg/dL) \\
\hline & $\mathrm{H}+15(24)$ & : Kadar Gula Darah H+15 Perlakuan jam ke- 24 (mg/dL) \\
\hline
\end{tabular}

Senyawa dalam daun pandan wangi yang diduga berperan dalam menurunkan kadar glukosa darah adalah flavonoid. Sampai saat ini mengenai mekanisme flavonoid dalam menurunkan kadar glukosa darah belum diketahui secara pasti, namun dari beberapa teori menyebutkan bahwa flavonoid diketahui mampu berperan dalam menangkap radikal bebas atau dapat berfungsi sebagai antioksidan alami. Aktivitas antioksidan tersebut memungkinkan flavonoid untuk menangkap atau menetralkan radikal bebas, sehingga dapat memperbaiki keadaan jaringan yang rusak. Flavonoid dapat berperan dalam kerusakan jaringan pankreas yang diakibatkan oleh alkilasi DNA akibat induksi aloksan sebagai akibatnya dapat memperbaiki morfologi pankreas tikus. Flavonoid dilaporkan memiliki aktivitas antidiabetes yang mampu meregenerasi sel pada pulau Langerhans (Prameswari, 2014). Flavonoid dapat mencegah komplikasi atau progresifitas diabetes mellitus dengan cara membersihkan radikal bebas yang berlebihan, memutuskan rantai reaksi radikal bebas, mengikat ion logam (chelating), dan memblokade jalur poliol dengan menghambat enzim aldose reduktase. Flavonoid juga memiliki efek penghambatan terhadap enzim alfa 
glukosidase melalui ikatan hidroksilasi dan substitusi pada cincin $\beta$. Prinsip penghambatan ini serupa dengan acarbose yang selama ini digunakan sebagai obat untuk penanganan diabetes mellitus, yaitu dengan menghasilkan penundaan hidrolisis karbohidrat dan disakarida dan absorpsi glukosa serta menghambat metabolisme sukrosa menjadi glukosa dan fruktosa (Soewonto, H. 2001; Mills, S and K. Bone. 2002; Ho, $\mathrm{E}$ and T.M. Bray. 1999). Kandungan senyawa yang terdapat pada daun salam diantaranya yaitu alkaloid dan saponin yang dapat menstimulasi sekresi insulin dari sel beta pankreas (Patel. et al, 2012; Murray. et al, 2003), serta terpenoid seperti triterpenoid dapat dapat meningkatkan penyerapan glukosa dengan bertindak meniru kerja insulin dan sebagai insulin sensitizer (Lee dan Thuong, 2010).

Standardisasi suatu simplisia tidak lain pemenuhan terhadap persyaratan sebagai bahan dan penetapan nilai berbagai parameter dari suatu produk. Standardisasi simplisia juga mempunyai pengertian bahwa simplisia yang akan digunakan untuk obat sebagai bahan baku harus memenuhi persyaratan yang tercantum dalam monografi terbitan resmi Departemen Kesehatan (Materia Medika Indonesia) (Depkes RI, 2000). Salah satu tujuan dari standardisasi adalah menjaga konsistensi dan keseragaman khasiat dari obat herbal.
Standardisasi melibatkan pemastian kadar senyawa aktif farmakologis melalui analisis kuantitatif metabolit sekunder yang akan menjamin keseragaman khasiat (Saefudin, et al., 2011). Standardisasi ekstrak daun pandan wangi (Pandanus amaryllifolius Roxb.) dan daun salam (Syzygium polyanthum Wight.) yang dilakukan di dalam penelitian ini adalah karakterisasi ekstrak berupa parameter spesifik sesuai acuan dari PPOMN (Depkes RI, 2000) meliputi kadar senyawa yang larut dalam air dan kadar senyawa yang larut dalam etanol. Penentuan kadar senyawa larut dalam air bertujuan untuk menunjukkan jumlah kandungan senyawa yang bersifat polar (memiliki sifat kepolaran sama dengan air). Penetapan kadar senyawa larut etanol dilakukan untuk menunjukkan kandungan senyawa-senyawa yang bersifat semi polar (memiliki sifat kepolaran sama dengan etanol). Etanol yang digunakan sebagai pelarut adalah etanol 96\% yang kemudian diuapkan di atas titik didih etanol $\left(80^{\circ} \mathrm{C}\right)$. Hasil karakterisasi simplisia daun pandan wangi dan daun salam yaitu penetapan kadar senyawa larut dalam air berturut-turut yaitu sebesar $11 \%$ dan 9\%, sedangkan kadar senyawa larut dalam etanol sebanyak 11\% dan 11\%. Berdasarkan hasil yang diperoleh, dapat diketahui bahwa kadar senyawa larut dalam etanol lebih tinggi dibandingkan dengan senyawa larut dalam air, artinya kadar senyawa semi 
polar lebih tinggi dibandingkan dengan kadar senyawa polarnya. Hal ini disebabkan karena pelarut dalam proses maserasi yang digunakan adalah etanol yang mana bersifat semi polar. Hasil yang diperoleh pada penetapan kadar senyawa larut air dan kadar senyawa larut etanol sudah sesuai berdasarkan MMI yang menyatakan bahwa persyaratan parameter spesifik kadar senyawa larut air yaitu $<24 \%$ dan kadar senyawa larut etanol $>6 \%$. Penetapan kadar senyawa larut dalam air dan etanol ini merupakan dugaan secara umum banyaknya senyawa yang bersifat polar (yang larut air) maupun bersifat semi polar (terlarut dalam etanol). Penetapan senyawa larut dalam air maupun etanol ini tidak secara langsung mempengaruhi efek farmakologis senyawa aktif dalam ekstrak (Saifudin, 2011).

Diabetes mellitus dapat disebabkan oleh banyak faktor. Faktor tersebut diantaranya faktor genetik, infeksi oleh kuman, faktor nutrisi, zat diabetogenik, dan radikal bebas (stres oksidatif). Senyawa aloksan merupakan salah satu zat diabetogenik yang bersifat toksik, terutama terhadap sel beta pankreas, dan apabila diberikan kepada hewan coba seperti tikus maka dapat menyebabkan hewan coba tikus menjadi diabetes. Mekanisme toksisitas aloksan diawali dengan masuknya aloksan ke dalam selsel beta pankreas dan kecepatan pengambilan akan menentukan sifat diabetogenik aloksan. Induksi aloksan pada dosis $150 \mathrm{mg} / \mathrm{kgBB}$ secara intraperotoneal mampu meningkatkan kadar glukosa darah dan kerusakan pada sel $\beta$ pankreas tikus. Tikus dinyatakan hiperglikemia bila kadar glukosa darah > 135 mg/dL (Giri, 2008).

Sebelum dilakukan perlakuan, Tikus Putih diadaptasikan terlebih dahulu dengan lingkungan selama 7 hari untuk menghindari terjadinya stres pada saat perlakuan. Sebelum perlakuan dimulai, tikus dipuasakan terlebih dahulu selama 16 jam agar terjadi pengosongan lambung oleh makanan yang dapat mempengaruhi hasil penelitian, tetapi tetap diberi minum.

Pada pengujian diabetes mellitus, 9 ekor tikus putih (Rattus norvegicus) dibagi menjadi 3 kelompok perlakuan. Masing - masing kelompok terdiri dari 3 ekor tikus. Kelompok yang diberi Insulin Pen dengan dosis $0,7 \mathrm{mg} / \mathrm{kg}$ BB tikus, kelompok diberi $\mathrm{Na} \mathrm{CMC} 1 \%$, dan Kelompok yang diberi suspensi kombinasi ekstrak daun pandan wangi dengan dosis $600 \mathrm{mg} / \mathrm{KgBB}$ tikus dan daun salam 625 $\mathrm{mg} / \mathrm{kgBB}$ tikus. Diberikan selama 15 hari dan diukur kadar gula darah tikus putih pada hari ke 3 dan hari ke 15. Sebelumnya terlebih dahulu diukur kadar gula darah puasa dan kadar gula darah setelah induksi aloksan. Diukur kadar gula darah tikus putih menggunakan alat glukometer.

Berdasarkan data penelitian pada tabel 4, rata-rata kadar gula darah hewan 
uji pada kelompok sebelum perlakuan dan sesudah perlakuan terdapat perbedaan bermakna. Kadar gula darah tikus sebelum induksi belum mengalami hiperglikemi ditandai dengan kadar gula darah masih terlihat normal dengan nilai $<125 \mathrm{mg} / \mathrm{dL}$, namun setelah diinduksi diabetes mengalami peningkatan kadar gula darah sehingga menyebabkan hiperglikemi dengan nilai $>125 \mathrm{mg} / \mathrm{dL}$. Pada $\mathrm{H}+3$ dan $\mathrm{H}+15$ jam ke- o, 6, 12, 18, dan 24 setelah pemberian perlakuan, diperoleh hasil pengukuran rata-rata kadar gula darah pada kelompok kontrol positif dan kelompok perlakuan ekstrak mengalami penurunan kadar gula darah, namun tidak terjadi penurunan pada kelompok kontrol negatif.

Berdasarkan hasil analisis statistik, menunjukkan bahwa kadar gula darah sebelum induksi diabetes dan sesudah induksi diabetes diperoleh hasil yang berbeda nyata tiap kelompoknya yaitu $\mathrm{p}<0,05$. Hal ini membuktikan bahwa induksi aloksan dapat merusak sel beta pankreas yang menyebabkan produksi insulin menurun sehingga terjadi peningkatan kadar glukosa darah. Selanjutnnya diberi perlakuan hingga $\mathrm{H}+15$ kemudian diukur kembali kadar gula darah tikus pada $\mathrm{H}+3$ dan $\mathrm{H}+15$.

Dalam penelitian tersebut, berdasarkan hasil analisis statistik diatas, $\mathrm{H}+3$ perlakuan jam ke-o, 6, 12, 18 dan 24 diperoleh hasil bahwa terdapat perbedaan yang bermakna $\quad(p<0,05)$ antara kelompok kontrol positif dan perlakuan ekstrak dibandingkan kelompok kontrol negatif dengan nilai signifikan $(p<0,05)$. Tidak ada perbedaan yang bermakna antara kelompok kontrol positif dan perlakuan ekstrak dengan nilai signifikan $(p>0,05)$. Selanjutnya hasil analisis statistik pada $\mathrm{H}+15$ perlakuan jam ke- o, 6, 12, 18, dan 24 juga menunjukkan adanya perbedaan bermakna pada kelompok perlakuan ekstrak dan kelompok kontrol positif dibandingkan dengan kelompok kontrol negatif dengan nilai signifikan masingmasing yaitu $(p<0,05)$. Kadar gula darah kelompok perlakuan mengalami penurunan setelah diberikan perlakuan ekstrak, sedangkan asil analisis pada kelompok kontrol positif dibandingkan perlakuan ekstrak menunjukkan tidak ada perbedaan yang bermakna baik pada jam ke- o, 6, 12, 18 dan 24, nilai signifikan $(\mathrm{p}<0,05)$.

Berdasarkan hal penelitian
diatas, sejalan dengan beberapa penelitian lainnya seperti penelitian yang dilakukan Prasmeswari, (2014) bahwa ekstrak daun pandan wangi dapat menurunkan kadar gula darah tikus yang diinduksi diabetes selama 4 minggu, dibandingkan penelitian saat ini lebih cepat efeknya dalam menurunkan kadar glukosa darah tikus disebabkan karena menggunakan kombinasi ekstrak daun pandan wangi dan daun salam yang 
efeknya saling sinergis dalam penurunan kadar gula darah dapat dilihat pada pengukuran $\mathrm{H}+3$ telah terjadi penurunan kadar gula darah hingga $\mathrm{H}+15$. Penelitian ini juga sejalan dengan penelitian Lolok et al. (2019) yang menggunakan kombinasi ekstrak kulit bawang merah dan kulit bawang putih dengan metode induksi aloksan terhadap tikus yang menyatakan bahwa ekstrak tanaman yang dikombinasi mempercepat penurunan kadar gula darah pada hewan coba tikus. Senyawa yang terkandung dalam daun pandan wangi dan daun salam mempunyai khasiat sebagai antidiabetes. Senyawa-senyawa yang terkandung dalam daun pandan wangi antara lain, tanin, alkaloid, flavonoid, dan polifenol. Flavonoid diketahui mampu berperan menangkap radikal bebas atau berfungsi sebagai antioksidan alami (Lugasi et al., 2003). Flavonoid dapat berperan dalam kerusakan jaringan pankreas yang diakibatkan oleh alkilasi DNA akibat induksi aloksan sebagai akibatnya dapat memperbaiki morfologi pankreas tikus. Flavonoid dilaporkan memiliki aktivitas antidiabetes yang mampu meregenerasi sel pada pulau Langerhans (Sandhar et al., 2011). Alkaloid terbukti mempunyai kemampuan regenerasi sel $\beta$ pankreas yang rusak (Arjadi, 2010).

Aktivitas antioksidan yang dimiliki ekstrak air daun pandan wangi juga tinggi yaitu $66.82 \%$ sehingga diduga mampu memperbaiki sel $\beta$ pankreas yang rusak. Aktivitas antioksidan mampu menangkap radikal bebas yang menyebabkan perbaikan pada kerusakan sel $\beta$ pankreas penyebab DM (Suryani, 2013). Dengan adanya perbaikan pada jaringan pankreas, maka terjadi peningkatan jumlah insulin didalam tubuh sehingga glukosa darah akan masuk kedalam sel sehingga terjadi penurunan glukosa darah dalam tubuh (Prasmeswai, 2014), dan senyawa kimia yang terdapat dalam daun salam yaitu flavanoid dimana kandungan flavonoid utama pada ekstrak etanol daun salam berupa kuersitrin dan fluoretin yang berfungsi sebagai antioksidan (Badan POM RI, 2004). Flavonoid bekerja dengan cara menghambat reabsorbsi glukosa dari ginjal (Lukacinova et al, 2008), mengatur kerja enzim yang terlibat pada jalur metabolisme karbohidrat, meningkatkan sekresi insulin (Brahmachari, 2011), sehingga mampu menurunkan kadar glukosa darah.

Berdasarkan uraian hasil penelitian diatas, dapat diketahui bahwa kombinasi ekstrak etanol daun pandan wangi dosis $600 \mathrm{mg} / \mathrm{kgBB}$ dan daun salam $625 \mathrm{mg} / \mathrm{kgBB}$ dapat menurunkan kadar gula darah pada tikus (Rattus norvegicus) putih galur wistar yang diinduksi diabetes. Menurut Wolfenshon dan Lloyd (2013) kadar gula darah normal 50-135 mg/dl. Penurunan kadar gula darah pada tikus yang terjadi 
masih dalam kategori normal, artinya tidak terjadi hipoglikemik. Pengaruh ekstrak etanol daun pandan wangi (Pandanus amaryllifolius Roxb.) dalam menurunkan kadar gula darah terjadi karena dalam ekstrak etanol daun pandan wangi terdapat kandungan tannin, alkaloid dan flavonoid. Tannin yang terdapat didalam daun pandan wangi akan memicu metabolisme glukosa dan lemak, yang nantinya digunakan untuk mencegah adanya timbunan glukosa dan lemak di darah (Dalimartha, 2005). Alkaloid akan menghambat sintesis glukosa dengan menghambat enzim glukosa 6-fosfatase dan fruktosa 1,6biofosfatase yang berfungsi menurunkan pembentukan glukosa dari substrat selain karbohidrat sehingga kadar glukosa darah turun (Arjadi, 2010). Flavanoid dengan mekanisme kerja menghambat GLUT2 (Glucose Transporter Isoform 2), suatu protein transporter glukosa pada membran usus (Song $\mathrm{J}$ et al, 2002) yang merupakan kendaraan pengangkut glukosa dari saluran cerna kemudian masuk ke dalam darah melewati membran menuju ke dalam sel (Sudoyo et al, 2006). Sehingga kadar gula darah tidak meningkat. Sedangkan kandungan senyawa yang terdapat pada daun salam diantaranya yaitu alkaloid dan saponin dapat menstimulasi sekresi insulin dari sel beta pankreas (Patel et al, 2012; Murray et al, 2003), serta terpenoid seperti triterpenoid dapat dapat meningkatkan penyerapan glukosa dengan bertindak meniru kerja insulin dan sebagai insulin sensitizer (Lee dan Thuong, 2010).

\section{KESIMPULAN}

Berdasarkan hasil penelitian setelah dianalisis secara statistik dan pembahasan maka dapat disimpulkan bahwa :

Kombinasi ekstrak Daun Pandan Wangi (Pandanus amaryllifolius Roxb.) dan Daun Salam (Syzygium polyanthum Wight.) memberikan efek dalam penurunan kadar gula darah serta memberikan hasil optimal yang hampir sama dengan kelompok positif dalam penurunan kadar gula darah dibuktikan dengan nilai signifikan yang tidak berbeda nyata $\mathrm{p}>0,05$.

\section{UCAPAN TERIMA KASIH}

Dengan selesainya penelitian ini, penulis mengucapkan terima kasih kepada semua pihak yang telah berkontribusi yaitu Dr. PH. Hj. Tasnim, S.KM., M.PH, selaku ketua STIKES Mandala Waluya Kendari, Apt. Waode Yuliastri, S.Farm.,M.Si selaku selaku Ketua Program Studi Farmasi STIKES Mandala Waluya Kendari, Staf Administrasi STIKES Mandala Waluya Kendari, Laboratorium Farmakognosi-Fitokimia dan Biofarmasi STIKES Mandala WaluyaKendari, mahasiswa(i) Program Studi Farmasi STIKES Mandala Waluya Kendari, serta seluruh pihak yang telah 
membantu selama penulis melakukan penelitian.

\section{DAFTAR PUSTAKA}

American Diabetes Association (ADA) (2014) Diagnoses and classification of diabetes mellitus, Diabetes Care 37(1): 81-90.

Anitha, M., Sakthidevi, G., Muthukumarasamy, S., dan Mohan, V.R., 2012. Effect of Cynoglossum zeylanicum (Vehl ex Hornem) Thunb. Ex Lehm on OralGlucose Tolerance in rats.

Arjadi, F., dan Susatyo, P., 2010, Regenerasi Sel Pulau Langerhans Pada Tikus Putih (Rattus norvegicus) Diabetes yang Diberi Rebusan Daging Mahkota Dewa (Phaleria macrocarp (scheff.) Boerl.),Efek Anti Diabetes Rebusan Buah Mahkota Dewa, 2 (2): 117-26.

Badan POM RI., 2004, Monografi Ekstrak Tumbuhan Obat Indonesia

Brahmachari, G., 2011, Bio- Flavonoids With Promosing Antidiabetic Potentials:A Critical Survey, Research Signpost.

Chang, C.L.T., Y. Lin, A.P. Bartolome, Y.C. Chen, S.C. Chiu, \& W.C. Yang. 2013.

Dalimartha, S., 2005, Ramuan Tradisional Untuk Pengobatan Diabetes Mellitus,Penebar Swadaya, Bogor.

Departemen Kesehatan RI. (2000). Parameter Standar Umum Ekstrak Tumbuhan Obat. Dirjen Pengawasan Obat dan Makanan.Volume 1: Jakarta

Ditjen POM, 1986. "Sediaan Galenik", Departemen Kesehatan Tepublik Indonesia, Jakarta

Dipiro, J.T., R.L. Talbert, G.C. Yee, G.R. Matzke, B.G. Wells, \& L.M. Posey. 2011. Pharmacotherapy: A Pathophysiologic Approach pp 1205, 1209-1211. New York: Mc Graw Hill Medical.

Doughari,J.H., 2012. Phytochemicals :Extraction methods, Basic Structures and Mode of Action as Potensial Chemotheraupetic Agents, Phytochemicals_A Global Perspective of thei Role in Nutrition and Health, Intech.

Etuk, 2010. Animals Models for Studying Diabetes mellitus. Agriculture and Biology Journal of North America 1:2, 130-134.

(FHI), F. H. I. (2009) Farmakope Herbal Indonesia. 1st edn. Jakarta: Departemen Kesehatan RI.
Ginting, E. (2013) Carotenoid extraction of orange-fleshed sweet potato and its application as natural food colorant, $\mathrm{J}$. Teknol. dan Industri Pangan, 24.

Giri, L.N. 2008. Potensi Antioksidasi Daun Salam : Kajian In Vivo Pada Tikus Hiperkolesterolemia dan Hiperglikemia. Skripsi. Fakultas Matematika dan Ilmu Pengetahuan Alam. Bogor

Harbone, J.B., 1987. Metode Fitokimia, Penuntun Cara Modern Menganalisa Tumbuhan, Terbitan II. ITB : Bandung

Harismah, K. dan Chusniatun, 2016. Pemanfaatan Daun Salam (EugeniaPolyantha) Sebagai Obat Herbal Dan Rempah Penyedap Makanan. WartaLpm, Pp. Vol .19 No. 2 110-118.

Ho, E and T.M. Bray. 1999. Antioxidants, NFKB Activation, and Diabetogenesis. Proc Soc Exp Biol Med. 1999 Dec: 222(3): 205-13

International Diabetes Federation. 2015. IDF Diabetes Atlas 7th Edition. Brussels: InternationalDiabetes Federation. http://www.diabetes atlas.org/. [Sitasi: 9 Februari 2017]. [Sitasi pada 18November 2016].

Kairupan,B.Y.,Wowor,M.P.,Mambo,C.2015. Pengaruh Pemberian Ekstrak Umbi Bawang Merah (Allium cepa L.) terhadap Kadar Gula Darah Tikus Wistar (Rattus novergicus) yang diinduksi dengan Aloksan. Jurnal e biomedik (eBM) 3:1, 4-5.

Lee, M. S., \& Thuong, P. T. (2010). Stimulation of Glucose Uptake by Triterpenoids From Weigela Subsessilis. Phytotherapy research, 24, 49-53.

Lenzen, S. 2007. The Mechanisms of Alloxan and Streptozocin- Induced Diabetes , Clinical and Experimental Diabetes and Metabolism.

Liliwirianis, et al . 2011. Preliminary Studies On Phytochemical Screening Of Ulam And Fruit From Malaysia. EJournalof Chemistry, Volume VIII.

Lolok, et al. 2019. Antidiabetic Effect Of The Combination Of Garlic Peel Extract (Allium sativum) And Onion Peel (Allium cepa) In Rats WithOralGlucose Tolerance Method. Research Joournal of Pharmacy and Technology. Fakultas Farmasi STIKES Mandala Waluya, Kendari.

Lucacinova, A., Mojzis, J., Benacka, R., Keller, J., Maguth, T., Kurila, P.,et, al., 2008, 
Preventive Effect Of Flavonoids On Alloxan- Induced Diabetes Mellitus In Rats, Acta Vet, brno, 77: 175-182.

Lugasi, A., J. Hovari, K.V. Sagi and L. Biro. The Role of Antioxidant Phytonutrients In The Prevention of Disease. Acta Biologica Szegediensis. 2003; 47: 119-125

Mills, S and K. Bone. 2002. Principles and Practice of Phytotherapy : Modern Herbal Medicine. Edinburgh, Scotland, Churral Livingstone

Murray, R. K., Granner, D. K., Mayes, P. A., \& Rodwel, V. W. (2003). Biokimia Harper (Vol. 25). Jakarta: Penerbit Buku Kedokteran EGC.

Nastiandari, D. J. (2016). Pengaruh Air Rebusan Daun Pandan Wangi (Pandanus amaryllifolius Roxb.) terhadap Kadar Glukosa Darah Tikus Jantan Galur Wistar yang Terbebani Glukosa. Skripsi. Fakultas Farmasi. Universitas Sanata Dharma:hal. 1-3.

Nublah., 2011, Identifikasi Golongan Senyawa Penurun Kadar Glukosa Darah Tikus Putih (Rattus norvegicus Berkenhout, 1769) Hiperglikemia pada Daun Sukun (Artocarpus altilis (park.) fosberg ), Tesis, Universitas Gajah Mada.

Nurarif, H.A \& Kusuma, H. (2015). Aplikasi Asyhan Keperawatan Berdasarkan Diagnosa Medis Nanda dan NIC-NOC. Yogyakarta : Medi Action

Nurhasnawati, H., Sukarmi dan Fitri H., 2017, Perbandingan Metode Ekstraksi Maserasi dan Sokletasi Terhadap Aktivitas Antioksidan Ekstrak Etanol Daun Jambu Bol (Syzygium malaccense L.), Jurnal Ilmiah ManuntungVol.3 No.1 : 3

Octavia, D.R., 2009, Uji Aktivitas Penangkap Radikal Ekstrak Petroleum Eter, Etil Asetat dan Etanol Daun Binahong (Anredera Corfolia (Tenore) Steen) dengan metode DPPH (2,2-difenil-1pikrihidrasil), Skripsi. Universitas Muhamadiyah, Surakarta.

Patel, D., Kumar, R., Laloo, D., \& Hemalatha, S. (2012). Natural Medicines From Plant Source Used For Therapy of Diabetes Mellitus: An Overview of Its Pharmacological Aspects. Asian Pacific Journal of Tropical Disease, 239-250.

Piero, M.N., Nzaro, G.M., dan Njagi, J.M., 2015. Diabetes mellitus-a devastating metabolic disorder. Asian journal of biomedical and pharmaceutical sciences, 5: 1.

Prahastuti, S., Tjahjani, S. dan Hartini, E., 2011. The Effect Of Bay Leaf Infusion (Syzygium Polyanthum (Wight) Walp) To Decrease Blood Total Cholesterol Level In Dyslipidemia Model Wistar Rats. Jurnal Medika Planta, P. Vol. 1 No.4.

Prasmeswari, O. M., dan Widjanarko, S. B., 2014. Uji Efek Ekstrak Daun Pandan Wangi, Jurnal Pangan dan Agroindustri, No. 2, Vol. 2, FTP Universitas Brawijaya, Malang, hal. 16 $-27$.

Pourcel, L., Routaboul, J,M et al., 2006, Flavonoid Oxidation In Plants: From Biochemical Properties To Physiological, Elsevier.

Radenkovic, et al. 2015. Experimental diabetes induced by alloxan and streptozotocin: The current state of the art. Journal of Pharmacological and Toxicological Methods.

Saifudin, A., Rahayu, V., \& Teruna, H. Y. (2011). Standardisasi Bahan Obat Alam. Yogyakarta: Graha Ilmu.

Sandhar, H.K., B. Kumar, S. Prashes, P. Tiwari, M. Salhan, P. Sharma. 2011. A Review Of Phytochemistry And Pharmacology Of Flavonoids. Internationale Pharmaceutica Scienca Jan-Mar 2011 Vol 1 Issue 1

Sharp, P., dan Villano, J., 2013, The Laboratory Rat, Edisi 2, 9-11, CRC Press, California.

Soewonto, H. 2001. Antioksidan Eksogen Sebagai Lini Pertahanan Kedua Dalam Menanggulangi Peran Radikal Bebas. Didalam: Prosiding Khusus Penyegar Radikal Bebas dan Antioksidan dalam Kesehatan : Dasar Aplikasi dan Pemanfaatan Bahan Alam. Jakarta 16 April 2011. Bagian Biokimia Fakultas Kedokteran Universitas Indonesia

Song J, Kwon O, Cheng S, Daruwala R, Eck P and Park JB, 2002, Flavonoid inhibitionof sodium-dependent vitamin ctransporter 1 (svctl) andglucose transporter isoform 2(glut2), intestinal transportersfor vitamin $\mathrm{c}$ and glucose, $\mathrm{J}$ Biol Chem.

Sornalakshmi, V., Tresina Soris, P., Paulpriya, K., Packia Lincy, M., dan Mohan, V.R., n.d. Oral Glucose Tolerance Test (OGTT) in Normal Control and Glucose Induced Hyperglycemic Rats 
with Hedyotis leschenaultiana DC. Group,1: 0-9.

Sumono, A. \& A. Wulan.2009. Kemampuan Air Rebusan Daun Salam (Eugenia polyantha W) dalam Menurunkan Jumlah Koloni Bakteri Spectroccocus sp. Majalah Farmasi Indonesia. 20 (3), 112-117.

Suresha, R.N., Sushma, V.N., Ashwini, V., Kalabharathi, H.L., Jayanthi, M.K., dan Prathima, C., 2012. The effect of nifedipine on oral glucose induced glycaemic changes in normal albino rats. pancreas, 10: 13

Suryani, N., T. Endang dan Aulanni'am. 2013. Pengaruh Ekstrak Metanol Biji Mahoni Terhadap Peningkatan Kadar Insulin, Penurunan Ekspresi TNF- $\alpha$ dan Perbaikan Jaringan Pankreas Tikus Diabetes. Jurnal Kedokteran Brawijaya, Vol. 27, No. 3, Februari 2013

Swastini, Dewa Ayu. 2018. Penurunan Kadar Glukosa Darah dan Gambaran Histopatologi Pankreas dengan Pemberian Gula Aren (Arenga pinnata) pada Tikus Jantan Galur Wistar yang Diinduksi Aloksan. Indonesia Medicus Veterinus. 7(2): 94105.

Szkuldelski, T. 2008. The Mechanism of Alloxan and Streptozotocin Action in B Cells of The Rat Pancreas. Physiol. Res. 50: 536-546, 2001

Szkudelski, T. 2001. The Mechanism Of Alloxan And Streptozotocin Action In $\beta$ Cells Of The Rat Pancreas, Physiology Research, 50: 536-54.

Tiwari, P., Kumar, B., Kaur, M., Kaur G. \& Kaur H., 2011, Phytochemical
Screening And Extraction: A Review, International Pharmaceutica Sciencia, 1 (1), 98-106.

Udia, P.M., Ogbonna, O.J., Antai, A.B., Mbatutung, I.F., dan Eyo, S.E., 2013. Oral glucose tolerance test and some haematological effects of aqueous leaf extract of Rothmannia hispida (K Schunn) Fargel on normoglycaemic albino rats. J.Pharmacog. Phytochemistry,5: 300-305.

Van Steenis, C.G.G.J., 2003, Flora, hal 233236, P.T. Pradya Paramita, Jakarta.

Van Steenis CGGJ. 2008. Flora, Cetakan ke-7. Jakarta: PT Pradnya Paramita

Van Steenis. 2008. Flora, Cetakan ke-12. Jakarta: PT. Pradnya Paramita

Widyawati PS, Budianta, and FA Kusuma. Difference of Solvent Polarity to Phytochemical Content and Antioxidant Activity of Pluchea indica Less Leaves Extracts, International Journal of Pharma cognosy and Phytochemical Research. 2014; 6(4): 850-5.

Winarto WP, Tim Karyasari. Mememanfaatkan bumbu dapur untuk mengatasi aneka penyakit. Jakarta: Agromedia Pustaka; 2004.p.50

Wolfensohn, S. dan Lloyd, M., 2013. Handbook of Laboratory Animal Management and Welfare., 4th Edition. ed. John Wiley \& Sons, Ltd.

World Health Organization. 2016. Global Report onDiabetes. France: World Health Organization. http://www.who.int/diabetes/globalreport/en/. [Sitasi: 29 Mei 2017]. 